hymns of the so-called Octoechus, he would have known that the words (330. 5) go together and mean 'we may offer praise to His many mercies'. While dealng with the appendix I may also note that in the extracts from Michael he has taken straight from M. Chabot the obvious blunder for for (312. 12) and its forced translation.

On several points questions arise which will perhaps be answered in the forthcoming commentary: e.g. at $24 \mathrm{I}$, note 3 , the citation from the life in the so-called Dionysius is described as from John of Asia, although it is hard to believe that John of Asia did not write before the composition of the life; and on p. 36I Theodore the Reader is stated to have written under Justin I, though the ninth passage cited from him deals with the reign of Justinian. Again, in a note on an extract from Evagrius (p. 380) September of the year $5^{67}$ of the Antiochene era is stated to be Sept. 518 ; but by comparison with Evagr. ii I2, iv I, 9 it would appear to be 519 ; and similarly the year $59^{2}$ at 374 , note 2 , should rather be 593 . There seems to be another chronological error at 365 , note 2 ; 536 is not the thirteenth, but the fourteenth indiction. I have noted small slips or misprints at 210 , note 4,242 , note 6 (' 242 ' for ' 249 '), 261 , note 5 (' $\mathrm{J}$ ' for ' A'), 282.4 (cf. note 1 ), 294, note 9 , and 319 , note 4 (words transposed).

In reviewing work of this kind it is necessary to occupy a large portion of the space in calling attention to faults and deficiencies, which thus appear to be much more numerous than they really are. In fact points to which reasonable objection can be taken are very few in proportion to the matter contained in the present fascicule, and M. Kugener must be heartily congratulated on having done so much to throw light on the career of the great Monophysite leader, about whom until the last few years little indeed was known; the full extent of his services will, however, be apparent only when his remaining fascicule sees the light. A similar tribute must at the same time be given to the enterprising editors of the Patrologia, MM. Nau and Graffin, who besides M. Kugener's work announce an edition of an unpublished Ethiopic life of Severus as in preparation by $\mathrm{Mr}$ Goodspeed.

E. W. Вкоокs.

\title{
THE LANGUAGE OF ST PAUL.
}

Der Wortschatz des Apostels Paulus, Beitrag zur sprachgeschichtlichen Erforschung des Neuen Testaments, von T. Nágel. (Vandenhoeck u. Ruprecht, Gottingen, 1905.)

ThIS pamphlet is a fragment, yet a very interesting fragment. It is indeed only an expanded preface to a lexicon of Pauline Greek which 
the author is contemplating and of which he has completed the portion that falls under the first five letters of the alphabet, and his work up to this point has been approved by the theological faculty of Basle as a thesis for the doctorate.

In this preface he draws out the inferences which seem to him to result from an induction based on this portion, and he applies his conclusions both to forming an estimate of the sources from which St Paul has drawn his vocabulary and to testing the genuineness of the various epistles.

The result of his examination is to minimize St Paul's indebtedness to the writers of classical Greek : he thinks there is no trace of conscious imitation of them. On the other hand, he also minimizes the direct Hebraisms in his style. The Apostle writes in the style natural to a Greek of Asia Minor adopting the current Greek of the time, borrowing more or less consciously from ethical writers, framing new words or giving a new meaning to old words in order to express new Christian ideas, but in the main using the language which inscriptions and papyri prove to have been the language of daily intercourse. His choice of vocabulary is therefore very much like that of Epictetus, save that his intimate knowledge of the LXX has modified it by the introduction of words or phrases which have arisen from the necessity of translating Hebrew. These points are illustrated and (it seems to me) proved by careful examination of the chief words which have been hitherto regarded as classical, or poetical, or archaic, and of those which St Paul shares with the LXX or writers of the Apocrypha.

The writer then applies the results thus gained as a test for judging the genuineness of the Epistles; he rightly regards I and 2 Corinthians as exhıbiting St Paul's style in its most normal stage ; Romans is more indebted to legal and ethical writers for its technical terms : Galatians is freer in the use of colloquial, if not vulgar, phrases; but in no case does the vocabulary suggest any doubt about the authorship, except in that of the Pastoral Epistles. Here the absence of ordinary Pauline words and particles, the large number of new words, and the many points of similarity with the vocabulary of the writers of the Old Testament Greek apocryphal books, make Dr Nageli doubt the Pauline authorship. But he admits that the likeness to the Apocryphal writers is to be found in all the Epistles, and that the general impression of similarity would only be softened, not removed, if the Pastoral Epistles were not taken into account. He also admits that in deciding the genuineness of a document, especially in the New Testament, the vocabulary is only one of the factors and can seldom say the last word.

On the whole, the pamphlet is a piece of thorough accurate work at detals, combined with soundness of judgement in drawing inferences 
from them, and it is much to be hoped that Dr Nageli will be able to complete the lexicon thus happily inaugurated. A useful list of authorities is added at the end.

WALTER LOCK.

\section{THE DOCTRINE OF THE EUCHARIST.}

Études d'Histoire et de Théologie positive. $2^{\mathrm{ièr} \theta}$ série. L'Eucharistie, la Présence réelle, et la Transsubstantiation. Par P. Batıffol. (Lecoffre, Paris, I905.)

IN this second series of 'Studies' Mgr Batiffol has produced a historical study which is a model of lucidity, conciseness, and careful exposition. The arrangement of the book is excellent and enables the reader to grasp with ease the main stages of the development of the doctrine of the Eucharist from the period of the New Testament to the Fourth Council of the Lateran. Another feature of the book is its historical candour. The passages which have so often been the battleground of controversialists are here carefully analysed in the dry light of historical investigation and placed in their true setting.

Mgr Batiffol defines the faith of the early church with regard to the Eucharist as a simple 'realısm'. It is the purpose of his book to shew how this simple faith passed through the later stages of reflection into a doctrine of the conversion of the elements, which finally attained its natural and legitimate development in the doctrine of transubstantiation. The first roo pages are devoted to the New Testament. The chief problems are clearly stated and recent theories are discussed, though necessarily with brevity. Mgr Batıffol is perhaps inclined to cut the knots of some of the difficulties by adopting rather too readily and positively some recent conjectures. Thus, while accepting the full text of Luke xxii $15^{-20}$ (in place of the shorter 'Western' text), he explains it as a doublet, $v v$. $15-18$ forming one account of the institution, $v \% .19,20$ being a second account. There is more to be said for his solution of the divergences between the Synoptists and St John by the adoption of the theory that the Last Supper was the Kiddûsh.

Mgr Battfol's presentation of the evidence of the Fathers as a whole calls for little criticism. There is, however, one conspicuous exception, the treatment of the famous passage of Irenaeus, c. Haer. 1v I8. 5, where Irenaeus states that after the invocation the bread is 'no longer

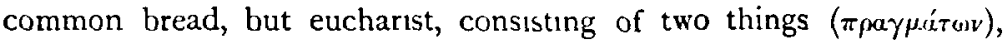
an earthly and a heavenly'. It is surely an evasion of the natural

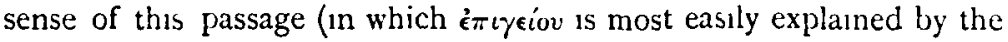

